International Journal of Business, Economics and Management

2020 Vol. 7, No. 6, pp. 4.27-441.

$\operatorname{ISSN}(e): 2312-0916$

$\operatorname{ISSN}(p): 2312-5772$

DOI: $10.18488 /$ journal.62.2020.76.427.441

(C) 2020 Conscientia Beam. All Rights Reserved.

check for
updates

\title{
INTERNATIONAL BUSINESS EXPANSION: THE ROLES OF AFFILIATION AND OWNERSHIP
}

\author{
Roxana Wright Plymouth State University, USA. \\ Email:rwrighto1@plymouth.edu Tel: oo1-603-254-9624
}

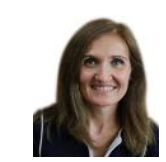

\section{Article History \\ Received: 17 August 2020 \\ Revised: 21 September 2020 \\ Accepted: 2 October 2020 \\ Published: 13 October 2020 \\ Keywords \\ International expansion \\ Affiliation \\ Ownership \\ Parent companies.}

$+2$

\begin{abstract}
The study provides a unique perspective that transcends firm motivations to understand business expansion outcomes, investigating the expansion connection with geography and the characteristics of the companies that pursue it. Specifically, the research evaluates whether selected factors related to the origin and location of expansion, the company's ownership status and affiliation, and the home and host regions predict a company's expansion actions as international or domestic. The study uses a random sampling research design and a large sample of instances of company expansion, defined broadly as direct and indirect investments and business development actions. The procedure investigates the phenomenon over the long run, with a focus on prediction. The analysis concludes that affiliation position determines expansion type, with parent companies more likely to pursue international expansion. The paper also offers better understanding of the regions where international business development is more likely, with comparative findings in North America and Europe.
\end{abstract}

Contribution/Originality: This study documents direct and indirect investments and business development actions based on a large data set, providing a unique perspective on international expansion. This study is one of very few studies which have investigated business expansion in the aggregate and in relation to business group affiliation and ownership status.

\section{INTRODUCTION}

International expansion continues to be of high interest to researchers, economists and managers. Traditionally, global expansion has been investigated from firm-level and country-level perspectives. Global expansion and the positive impact of firm-specific advantages are well-documented in international business theories. Extant research strands addressing firm-specific advantages discussed monopolistic advantage (e.g., (Hymer, 1976)) internalization and transaction costs (e.g., (Buckley \& Casson, 1976)), and international diversification (e.g., (Allen \& Pantzalis, 1996)). These theories agreed on the multinational enterprise's predilection to expand internationally in order to internalize transactions and exploit new business opportunities in other countries. According to internalization theory, Rugman (1981) argued that multinational enterprises combine their firm-specific advantages with country-specific advantages to gain competitive advantages in internationalization. Recent literature (Mauri, Song, \& Neiva de Figueiredo, 2017) confirmed that multinational enterprises must redeploy and adapt their firm-specific advantages to the characteristics of host markets. Recent articles reflected on the regionalization observed in recent decades. Observations included the fact that the majority of sales of the 
world's 500 largest firms occurred in the three triad regions (North America, Europe, and Asia/Pacific). The highest portion of these companies' sales has been concentrated in their respective home regions (e.g., (Oh, Kim, \& Shin, 2019). This trend has been explained by the lower liability of foreignness (Qian, Li, \& Rugman, 2013) and the trends towards regional economic integration (Verbeke \& Kano, 2012). A major related research stream (e.g., (Ghemawat, 2005)) previously sought to explain the predominance of home region sales with the notion of distance: greater distances (cultural, administrative, geographic, or economic) reduce the transferability and exploitation possibility of non-location-bound firm-specific advantages and contribute to the concentration of sales and assets in the home region. A related body of literature addressed the regionalization of firms. This extant work paid attention to the firm-level resources and capabilities, as well as the various market motivators. Recent studies (e.g., (Ariño, 2015; Oh et al., 2019) found evidence for semi-globalization. These studies have used small samples and focused on select groups of companies (e.g., large European multinationals, Fortune 500 firms, etc.).

The present research acknowledges previous work related to international activities and uses a larger viewpoint to examine the expansion as a phenomenon. The perspective is big-picture, with the goal to generalize at the aggregate level. Just as other recent studies (Christian, Zhang, \& Salifou, 2016) recognized, this study affirms that countries are different in terms of economic growth, overall development, market size and potential, culture, etc. These aspects may determine a country's attractiveness for investments from domestic and foreign firms. The present study is not concerned with the firm-level choices and the potential motivations. Rather, the analysis aims to identify how the choices of investment look like comprehensively and what may impact these choices at a macro level. The purpose of this article is to contribute to the literature on international expansion by investigating the predilection of cross-border and home-country expansion and the key factors that make a difference. The exploration is based on a large and recent data set that uniquely integrates regional aspects, industry and company status. A study of business expansion is timely. The information used for this investigation includes extensive data covering the past decade. According to the International Monetary Fund's World Economic Outlook, recent developments affecting growth and investments include trade policy differences, Brexit, geopolitical tensions, and weaker-than-anticipated global activity. Firms and households continue a trend of holding back on long-term spending, and global trade remains sluggish. As a result of the COVID-19 pandemic, the global economy is projected to contract sharply by -3 percent in 2020, with global economy projected to grow in 2021, helped by policy support. The current study connects the state of the economy with international business expansion. If geography and economic variables determine the overall focus of business expansion towards domestic or towards international activities, we will be able to predict business development and expansion directions in the future.

\subsection{Theoretical Background}

The present study follows strands of internationalization theory and echoes investigations and findings of classic and current works. The aim is to predict whether expanding internationally is more likely if the company's home economy is strong. In addition, the study examines if growing investments in an economy attract international actions. This research explores whether a company's affiliation position and ownership status impact the probability of international business expansion (versus domestic business expansion). The model also tries to predict whether a company's expansion actions are international or domestic depending on the region where the company is located and on the region where the expansion takes place. Finally, the study explores if industry sector should be included in the investigation of international versus national expansion.

Existing literature (Desai, Foley, \& Hines Jr, 2005) found evidence that firms tend to expand foreign operations and domestic operations simultaneously. Foreign and domestic investments are complements rather than substitutes. The present research intends to test whether certain factors may determine the probability of foreign versus domestic expansion, for any one instance of expansion. This study takes a broader view on business expansion, to include direct but also indirect and additional investments, such as market growth via increased 
distribution, partnering, and expanding capacity of existing operations. The same previous work (Desai et al., 2005) conjectured that poor domestic investment opportunities could be the force behind the reallocation of funds to more profitable foreign opportunities. To verify a similar situation in the context of general expansion (not just foreign direct investment), the present research includes the home gross domestic product and the host capital formation growth as independent variables. Home gross domestic product shows the size of domestic economy, and provides a good comparable measure of scale. Host capital formation growth paints a picture of investment and growth of the "real economy". The rate of capital growth typically accounts for a significant proportion of economic growth (a correlation tested in more recent research, such as Gibescu (2010)).

Research on factors that affect how firms choose to internationalize (Dunning, 1988), and the agenda (Rienda, Claver, \& Quer, 2013) on the significance of industry technological intensity, host country risk, host market attractiveness, and previous international experience of the firm, are not central to this study. This paper has a larger scope of analyzing expansion in aggregate. Nevertheless, the above research streams contribute to arguments on external factors variables included in the analysis: overall size of the market/economy, capital formation growth and industry. Reinforcing the first item, it has been shown that host market size increases the attractiveness for foreign direct investment (in the studies above as well as Chakraborty and Basu (2002). Research has used gross domestic product to measure market attractiveness extensively (Rienda et al., 2013). The present research takes into consideration the market attractiveness of the home country as a motivation for companies to expand domestically, rather than internationally.

As synthesized in studies such as Nuruzzaman and Singh (2017) the influence of home and host market institutions on multinational enterprises' strategies has held scholars' attention for decades. Nuruzzaman and Singh (2017) found for the logic of institutional escapism. In a report on emerging market firms, the authors described that weak or inefficient home institutions add to the complexity of the domestic external environment, which, in turn, provide motivations for firms to escape into international markets. The present study recognizes the importance of the frameworks that link home and host environments to companies' internationalization. The specifics of how institutional leverage or institutional escapism shape decisions are not essential to this work. The perspective is larger, and, as such, overarching measures of the size, strength and geographical region of the home and host environments are considered. Institutional theory has long offered important insights in international business literature (Dunning \& Lundan, 2008). While not directly applicable in this research, institutional theory (North, 1990) explains the inclusion of country-level variables. The theory argued that constitution, legal framework, and informal constraints determine the business potential of a country. Recently, researchers (such as Lynch and Jin (2016)) have proposed new frameworks that relate to the cause rather than the outcome of theories considering country level issues influencing international business decisions. The capital formation variable is warranted by this perspective. In this paper, the investigation follows the latest strands of literature (e.g., Oh et al. (2019)) on firms' international expansion paths, geographic scope and how these aspects may differ across industries. Firms across industries seem to take distinctive paths of international expansion with markedly different geographic scope of operation. For instance, researchers (e.g., Moore, Fernie, and Burt (2000)) noted that certain business expansion patterns are specific to retailers. It was shown that Ireland and France were the most popular destinations for UK retailers, with other patterns reported in other European markets, such as German retailers expanding in Denmark and Austria, and Swedish retailers moving into other Scandinavian markets. These businesses tend to have larger geographical dispersion and their foreign market selection may differ from how manufacturers or firms in other industries make the selection (Mohr \& Batsakis, 2018). Hence, industry is an important independent variable in the model of business expansion. The large data set and variety of industry in the current study provide great opportunities to expand the understanding on the importance of industry. Thus, this study contributes to the literature connecting internationalization and industry. Classic works (e.g., Dunning (1988)) emphasized the various industry elements that impact the geographic scope of firms' international 
expansion: life cycle, industry competition, factor endowments, and industry characteristics. These works posited that multinational enterprises in the same industry share common industry characteristics and environmental factors. More recent work (Anand \& Delios, 2002) discussed how certain industries have attracted high levels of foreign direct investment, adding reason for including industry as a variable in the examination of business expansion. The present study is intentionally looking at high-level, aggregate expansion data, rather than at the individual firms' decisions or motivations for expansion. Whilst the framework considers country economy size and growth and the "pull" of the region, the model does not include specific variables related to cultural and geographical distance. This is due to findings (Li, Zhang, \& Shi, 2019) showing that foreign countries that seem to be good fits when considering geographic distance may be misfits when considering cultural distance, and vice versa. The present work is considering geographic locality.

Traditional internationalization theory points to regional expansion as an antecedent to global expansion (e.g. Dunning (1993)). More recently, scholars argued that trends such as rising liberalization of regional economies and the formation of regional economic blocs have created opportunities for firms to internationalize to regional markets (e.g. Ibeh, Wilson, and Chizema (2012)). Regional protectionism also motivates firms to pursue regionalization strategy (Wang et al., 2012). The present study uses such findings to consider the home region and the region where expansion takes place as important variables that may impact the inclination towards international versus home-country expansion.

Newer research explored the importance of entrepreneurial orientation and regional expansion. When considering the saturation of home markets and entrepreneurial opportunities, Boso, Oghazi, and Hultman (2017) showed that regional expansion is tied to companies' competitive aggressiveness and relationship management abilities. These findings have a different focus - on individual company entrepreneurial actions - than the current work. Nevertheless, they point to the validity of considering the expansion region. Also, this strand of literature gives impetus to a need to understand the impact of the home economy status (e.g., market saturation) and the opening of entrepreneurial opportunities abroad. Hence, there is additional support (from the one discussed above) for the inclusion of home gross domestic product (size of the home economy) and the host capital formation (i.e., growth in the country of expansion) in the current analysis.

One of the independent variables included in this model is ownership, in line with existing literature (e.g., Moore et al. (2000). Researchers found associations between private or public ownership and the firms' desire to exploit international potential and to pursue foreign expansion. For instance, a change in ownership status was found to be an impetus for an increase in international involvement. Authors (Moore et al., 2000) explored how public ownership and share issue revenue provided opportunities for increasing international involvement. Public companies benefit from access to public markets to raise new money and from relatively higher liquidity (being able to easily sell shares). Notionally, these companies have improved access to funds, which can be used for growth, mergers and acquisitions, or other corporate purposes. These benefits might be expected to aid in the international growth and expansion context. The relationship between public ownership and international sales or expansion may be moderated by the industry (e.g. Moore et al. (2000)), analyzed retailers only, in the context of international growth in demand for designer-branded products in recent years). This research observed that, in order to compete in an expanding global market, some companies have shed their independent status and became public companies. The research showed that the direction of international expansion has followed similar patterns to previous research on retail internationalization. Companies have targeted geographically close markets prior to moving into other geographic markets. Going public has ensured additional growth in new markets, such as Eastern Europe.

Group affiliation is also an important variable in this study. Group-affiliated firms are connected through ownership and financial interlinkages. Group affiliation has been considered in the literature (e.g., (Gupta \& Mahakud, 2018) as a determinant of investment decisions. Research (Gaur, Pattnaik, Lee, \& Singh, 2016) has found a positive relationship between the multinational corporation's business group affiliation and the financial 
performance as well as the survival of the foreign subsidiary. The authors explained the advantages network forms of organization possess to compete in domestic and international markets. The present analysis checks whether such advantages tip the expansion towards international reach.

The relationship between business group affiliation and corporate investments has been explained in the previous literature as a reaction to inefficient and costly capital markets. Business groups can fund investment projects through internal capital markets, and have better access to external capital due to scale and reputation. Researchers (Gupta \& Mahakud, 2018) explored the impact of group affiliation on the investment behavior of Indian manufacturers. They found that business group affiliation affected the corporate fixed investment positively. The authors' findings provide support for the present study. If fixed investment is affected, it is reasonable to test whether expansion decisions (involving fixed investments in infrastructure and operations but also non-fixed investments in distribution arrangements) are also shaped by group affiliation.

A number of researchers (e.g. (Gaur \& Kumar, 2009)) discussed the fact that the benefits of group affiliation may be context-dependent. As the context changes, group affiliation may no longer remain beneficial, even in domestic markets. This strand of literature have shown that group affiliation may be a liability for firms operating in a developed institutional environment. Group-affiliated firms fail to compete against unaffiliated firms in domestic markets. These firms may also find it difficult to translate benefits of affiliation in a variety of country and institutional contexts. The costs of group affiliation tend to magnify when a company diversifies into foreign markets (Gaur \& Kumar, 2009). The consideration of different types of business group affiliation and lack thereof is also granted by writings that discovered varying business expansion patterns depending on company type. For instance, articles such as Ambos, Andersson, and Birkinshaw (2010) brought evidence of subsidiaries taking significant actions in international expansion, such as international business development, major investments and entrepreneurial undertakings. As illustrated in the literature review, the present paper fits key frameworks from existing theory, but also takes an aggregate view that allows findings to show outcomes of business expansion in the context of regional and country environments. Previous studies (e.g., (Oh et al., 2019)) noted that extended sample time intervals provide value in the understanding of international expansion patterns. The current analysis uses a random sampling research design and a large sample of instances of company expansion. The empirical model examines selected factors discussed in the literature as potential variables that may increase the probability of international versus national (domestic) expansion. The procedure is justified by the investigation of the phenomenon over the long run, with a focus on prediction, not trend.

\subsection{Research Question and Hypotheses}

- The overall goal of the present study is to establish if there is a relationship between the kind of business expansion - international or domestic - and the following set of predictors: home economy size, host country investment growth, company ownership and business group affiliation, origin and location of expansion, and industry. More specifically, the research investigates whether international business expansion (versus domestic) can be predicted from conditions in the home and host countries as well as business status/ownership and affiliation type, while controlling for regional pull and industry. The purpose is to find which of these variables predict international expansion and how each may affect the business expansion orientation towards inside or outside the borders. The analysis investigates if each particular variable increases or decreases the probability of international business expansion, or if it has no effect on it. The ideas are captured in the following hypotheses:

Hypothesis 1: Home economy size influences the predilection for international business expansion. As indicated by the literature, positive conditions in the home country may be a motivation for companies to keep their expansionary initiatives local. A strong economy may present an opportunity for low-risk high-return investments. 
Hypothesis 2: Capital formation growth in the host country affects the probability of expansion activities from overseas. Extant works have showed that the growth of the "real economy" typically drives economic growth. In the current study, the aim is to find if high growth supports mostly domestic business activity, or if it increases the probability of international business activity.

Hypothesis 3: Public companies are more likely to engage in international business expansion. Previous analyses found that public ownership may offer an impetus for international business growth, as companies can raise and access funds more readily than privately-owned firms.

Hypothesis 4: Business group affiliation has an impact on the probability of international business expansion. The literature had inconsistent findings on the benefits of affiliation as related to investment and growth. Some works noted the increase in international business development from subsidiaries. The current analysis aims to find if there is a relationship between company affiliation as a parent, subsidiary, joint venture or independent, and an international expansion orientation.

While not formalized in hypotheses, the inclusion of other variables identified in the literature review - regional location and scope - provides for relevant findings on the probability of companies from certain regions to expand outside national borders, and whether certain regions exert a pull towards more international business activity. The analysis also brings attention to the mitigating effects of the industry. Previous research showed that some trends in international versus domestic expansion may be determined by industry sector characteristics. It is therefore noteworthy to explore how industry shapes business expansion.

\section{METHODOLOGY}

The study explores instances of international and domestic business expansion for the past decade. The source of data on business expansion is the MarketLine Advantage, a publisher of business information and companies, industries and geographies' profiles. This source provides real-time news with associated analytics. The "News" database inside MarketLine Advantage was used to identify announcements and press releases about individual company's actions of business expansion. The database provides a classification of news categories, which includes company strategic actions, and, specifically, business expansion. The current analysis uses the MarketLine Advantage classification of business expansion, which includes direct and indirect, or partnership-based actions: facilities extensions, expanded facility capacity, re-openings or new location openings, capital investments, distribution widening or delivery expansion, significant increases in scale of operations via hiring, and new largescale projects. The news database includes information on each company that is the focus of a business expansion news piece, such as home country and the location of the expansion initiative. These items are used to identify the region where the expansion originates and the region where the expansion takes place, and to categorize the business expansion as domestic (inside the home country) or international (outside the home country). Other key data collected from this source are the company subtype (as private or public), as well as affiliation mode (parent, subsidiary, joint venture or independent) and the industry sector (using the classification employed by the source).

Data were collected for 1099 instances of company business expansion from November 30th, 2009 to August, 21st, 2019. Only data on selected industries are included. Industries such as aerospace and defense, agriculture and forestry, construction and real estate, energy and utilities, financial services, government and non-profit organizations, media and digital entertainment, metals and mining, paper and packaging, pharmaceuticals and healthcare, telecoms and IT, tourism, leisure and hospitality, and transportation, infrastructure and logistics are considered as potentially not comparable in market structures, infrastructure and trends, and are left outside the focus of this study. The data set comprises instances of expanding companies of various affiliation positions and ownership status. The analysis is intentionally limited to business expansion in three regions: Canada, Europe and the U.S., from companies located anywhere in the world. For the purpose of this study, the countries of Canada and the U.S. are considered as regions, for easy comparisons with Europe as a region. The European countries for the 
analysis are: Austria, Belgium, Bulgaria, Croatia, Cyprus, Czech Republic, Denmark, Estonia, Finland, France, Germany, Greece, Hungary, Ireland, Italy, Latvia, Lithuania, Luxembourg, Malta, The Netherlands, Poland, Portugal, Romania, Slovakia, Slovenia, Spain, Sweden, United Kingdom.

These geographical locations were chosen due to their high amounts of instances of business expansion, which allow for an extensive data set from which to draw conclusions about predictive factors. The contrasts are the researcher's interest. The grouping of European countries (i.e., the consideration of Canada and the U.S. as regions) makes comparisons and statistical investigations possible, providing some balancing of the data. Most expansion instances are originating from the U.S., followed by Europe and Canada, with the fewest cases from other locations. The representations across the three regions of focus where expansion takes place are similar. The breakdown by expanding company's affiliation and ownership is shown in Table 1a and 1b. Table 1c shows the breakdown by industry. In order to investigate the size of each company's home economy, Gross Domestic Product (GDP) data (GDP in current prices, US Dollars, year of expansion) were collected from the International Monetary Fund. Gross capital formation (in current US Dollars) data were extracted from the World Bank national accounts data and OECD National Accounts data files. As defined by the source, this indicator consists of outlays on additions to the fixed assets of the economy plus net changes in the level of inventories. The gross capital formation data corresponding to each country where expansion takes place (in the expansion year) indicates the host country development and growth.

Table-1a. Sample distribution of expanding companies by affiliation.

\begin{tabular}{c|c}
\hline Expanding company affiliation & Total samples \\
\hline Parent & 449 \\
\hline Subsidiary & 224 \\
\hline Joint venture & 10 \\
\hline Independent & 402 \\
\hline Total & 1085 \\
\hline
\end{tabular}

Table-1b. Sample distribution of expanding companies by ownership.

\begin{tabular}{c|c}
\hline Expanding company ownership & Total samples \\
\hline Public & 377 \\
\hline Private & 708 \\
\hline Total & 1085 \\
\hline
\end{tabular}

Table-1c. Sample distribution of expanding companies across selected industries.

\begin{tabular}{c|l|c}
\hline No. & Expanding company's industry & Total samples \\
\hline 1 & Automotive & 27 \\
\hline 2 & Business and consumer services & 99 \\
\hline 3 & Chemicals & 33 \\
\hline 4 & Consumer goods & 140 \\
\hline 5 & Industrial goads and machinery & 62 \\
\hline 6 & Retail, wholesale and foodservice & 724 \\
\hline Total & & 1085 \\
\hline
\end{tabular}

The investigation uses logistic regression. The binomial logit model is common in the literature on internationalization (e.g., (Rienda et al., 2013)). This technique has no assumptions about the distributions of the predictor variables, which do not have to be normally distributed, linearly related or of equal variance. Maalouf (2011) promotes the usefulness of logistic regression for binary data classification, especially in circumstances that describe "imbalanced" data. Particularly useful for the present analysis is the fact that logistic regression predictors can be any mix of continuous, discrete and dichotomous variables. According to Meyers, Gamst, and Guarino (2016) the estimates in logistic regression provide the S-shaped logistic function that relates predictors to 
probabilities of certain events. The estimated coefficients for continuous, discrete and dichotomous variables are therefore expected to be numerical. The technique emphasizes the probability of a particular outcome for each case.

The model used for statistical analysis is formulated as follows:

$$
\mathrm{E}(\mathrm{y})=\exp (\mathrm{u}) /(1+\exp (\mathrm{u})) \text {, where }
$$

$y=$ Expansion and $u=\beta_{0}+\beta_{1}$ GDPHQ $+\beta_{2}$ GFCFExp $+\beta_{3}$ Ownership $+\beta_{4}$ Affiliation $+\beta_{5}$ HQ $+\beta_{6}$ Region $+\beta_{7}$ Industry.

The probability of international business expansion (versus national/domestic business expansion) can be calculated as:

$\mathrm{P}$ (International expansion) $=$

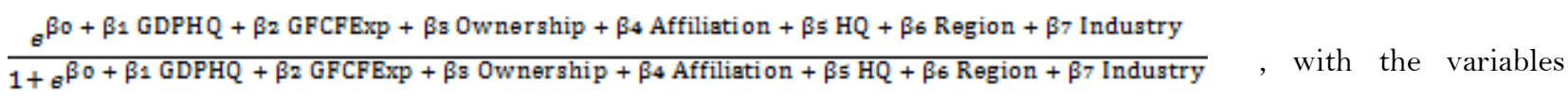
definitions and measurement information summarized in Table 2.

Table-2. Variables, measurement and data sources summary.

\begin{tabular}{|c|c|c|c|}
\hline Variable & Definition & Measurement & Source \\
\hline \multicolumn{4}{|l|}{$\begin{array}{l}\text { Dependent } \\
\text { variable }\end{array}$} \\
\hline Expansion & $\begin{array}{l}\text { An instance (news piece or press release) of } \\
\text { a company's strategic action of expansion } \\
\text { (via investment or distribution, individual } \\
\text { or in partnership) }\end{array}$ & $\begin{array}{l}\text { Categorical scale identifying whether } \\
\text { the company expands in the home } \\
\text { country (domestic/national expansion) } \\
\text { or outside the home country } \\
\text { (international expansion) }\end{array}$ & $\begin{array}{l}\text { MarketLine } \\
\text { Advantage News } \\
\text { Database }\end{array}$ \\
\hline \multicolumn{4}{|l|}{$\begin{array}{l}\text { Independent } \\
\text { variables }\end{array}$} \\
\hline GDPHQ & $\begin{array}{l}\text { Gross domestic product (GDP) in the } \\
\text { home country. Identifies GDP in current } \\
\text { US Dollars, in the year of each instance of } \\
\text { business expansion, in the country where } \\
\text { the company is headquartered }\end{array}$ & Numerical, in billions & $\begin{array}{l}\text { International } \\
\text { Monetary Fund } \\
\text { Datasets }\end{array}$ \\
\hline GFCFExp & $\begin{array}{l}\text { Gross fixed capital formation as total } \\
\text { volume growth from the previous year in } \\
\text { the country where expansion takes place, } \\
\text { in the year of expansion }\end{array}$ & $\begin{array}{l}\text { Percentage change from previous } \\
\text { period }\end{array}$ & $\begin{array}{l}\text { World } \\
\text { national accounts } \\
\text { data and OECD } \\
\text { National } \\
\text { Accounts data } \\
\text { files }\end{array}$ \\
\hline Ownership & $\begin{array}{l}\text { An identifier of the expanding company's } \\
\text { status }\end{array}$ & $\begin{array}{l}\text { Two-item scale identifying the status } \\
\text { of the company as publicly- owned } \\
\text { (public) or privately-owned (private) }\end{array}$ & $\begin{array}{l}\text { MarketLine } \\
\text { Advantage News } \\
\text { Database }\end{array}$ \\
\hline Affiliation & $\begin{array}{l}\text { An identifier of the expanding company's } \\
\text { affiliation type }\end{array}$ & $\begin{array}{l}\text { Four-item scale that categorizes an } \\
\text { expanding company's business group } \\
\text { affiliation position as: parent, } \\
\text { subsidiary, joint venture, or } \\
\text { independent }\end{array}$ & $\begin{array}{l}\text { MarketLine } \\
\text { Advantage News } \\
\text { Database }\end{array}$ \\
\hline \multicolumn{4}{|l|}{$\begin{array}{l}\text { Control } \\
\text { variables }\end{array}$} \\
\hline $\mathrm{HQ}$ & Home region of the expanding company & $\begin{array}{l}\text { Categorical scale categorizing home } \\
\text { region as: Canada, Europe, U.S., Other }\end{array}$ & $\begin{array}{l}\text { MarketLine } \\
\text { Advantage News } \\
\text { Database }\end{array}$ \\
\hline Region & $\begin{array}{l}\text { The host region as the region where the } \\
\text { expansion action is taking place. The three } \\
\text { regions correspond to the focus of the } \\
\text { study }\end{array}$ & $\begin{array}{l}\text { Categorical scale categorizing host } \\
\text { region as: Canada, Europe, U.S. }\end{array}$ & $\begin{array}{l}\text { MarketLine } \\
\text { Advantage News } \\
\text { Database }\end{array}$ \\
\hline Industry & $\begin{array}{l}\text { Expanding company's industry of } \\
\text { operation }\end{array}$ & $\begin{array}{l}\text { Categorical, identifying industry } \\
\text { sector: automotive, business and } \\
\text { consumer services, chemicals, } \\
\text { consumer goods, industrial goods and } \\
\text { machinery, retail, wholesale and } \\
\text { foodservice }\end{array}$ & $\begin{array}{l}\text { MarketLine } \\
\text { Advantage News } \\
\text { Database }\end{array}$ \\
\hline
\end{tabular}




\section{RESULTS}

From the entire data set, 1084 valid cases (with complete information on all variables) were included in the statistical analysis. The results of the logistic regression find no inordinately large parameter estimates or standard errors, which means that there is no reason to suspect a problem with outcome groups being perfectly predicted by any variable. There is also no indication of violation of the linearity in the logit for the model proposed. The results show no problem with convergence. No multicollinearity is evident. There are no outliers. The full model has strong predictive power, also supported by the large sample size, known to lead to high levels of statistical significance (Astivia, Gadermann, \& Guhn, 2019). Analysts noted the benefits of a large sample size for unbalanced binary variables. Large sample sizes are required when the distributions of the predictors are not symmetric or balanced. The overall correct classification percentage for the full model is improved both from the null model (not reported for brevity) and from the model including only the key predictors identified in the formal hypotheses. This indicates that the complete model, with the key variables and the control variables is warranted. The complete model is accurate in its prediction $86 \%$ of the time. Table $3 \mathrm{a}$ and $3 \mathrm{~b}$ summarize the results of the logistic regression analyses.

Table-3a. Summary of logistic regression analysis for key variables predicting international business expansion.

\begin{tabular}{|c|c|c|c|}
\hline $\begin{array}{c}\text { Omnibus test of model } \\
\text { coefficients }\end{array}$ & Chi-square $=199.329$ & Sig. $=.000$ & \\
\hline $\begin{array}{c}\text { Measures of strength of } \\
\text { association }\end{array}$ & $\begin{array}{c}\text { Cox and Snell R-square } \\
=.168\end{array}$ & $\begin{array}{c}\text { Nagelkerke R-square }= \\
.288\end{array}$ & $\begin{array}{c}-2 \text { Log likelihood }= \\
749.085\end{array}$ \\
\hline Classification & $\begin{array}{l}\text { Overall percentage } \\
\text { correct }=84.0\end{array}$ & & \\
\hline Variables in the equation & Coefficient & Wald & Sig. \\
\hline GDPHQ & $.000^{* *}$ & 150.636 & .000 \\
\hline GFCFEexp & -.008 & .129 & .719 \\
\hline Ownership & -.319 & 2.249 & .134 \\
\hline Affiliation & $-.205^{*}$ & 5.982 & .014 \\
\hline
\end{tabular}

Table-3b. Summary of logistic regression analysis for key and control variables predicting international business expansion.

\begin{tabular}{|c|c|c|c|}
\hline $\begin{array}{c}\text { Omnibus test of model } \\
\text { coefficients }\end{array}$ & Chi-square $=292.053$ & Sig. $=.000$ & \\
\hline $\begin{array}{c}\text { Measures of strength of } \\
\text { association }\end{array}$ & $\begin{array}{c}\text { Cox and Snell R-square } \\
=.236\end{array}$ & $\begin{array}{c}\text { Nagelkerke R-square }= \\
.405\end{array}$ & $\begin{array}{c}-2 \text { Log likelihood }= \\
656.362\end{array}$ \\
\hline Classification & $\begin{array}{c}\text { Overall percentage } \\
\text { correct }=86.0\end{array}$ & & \\
\hline GFCFEexp & -.007 & .089 & .765 \\
\hline Ownership & -.227 & .974 & .324 \\
\hline Affiliation & $-.190^{*}$ & 4.456 & .035 \\
\hline $\mathrm{HQ}$ & $2.615^{* *}$ & 37.471 & .000 \\
\hline
\end{tabular}

The results indicate that the goodness-of-fit is strong, with a chi-square that is highly significant in both the model with the key predictors only (chi-square $=199.329, \mathrm{p}<.000$ ) and also in the full model (chi-square $=292.053$, $\mathrm{p}<.000)$. The log-likelihood is decreased in the full model, suggesting that the accuracy of the model improves with the inclusion of the control variables. This conclusion is also supported by the increase in the strength of association measures when the control variables are included (Cox and Snell R-Square equal to 0.236 for the full model as compared to 0.168 for the reduced model, and Nagelkerke R-Square of 0.405 for the full model from 0.288). These measures are considered to be absolute measures of the validity of models (Meyers et al., 2016). The comparative 
results of alternative models show that both sets of predictors reliably predict the kind of business expansiondomestic or international. Since the more complete model (the model with all variables, including home region, region of expansion and industry) is more robust, the ensuing interpretation of results is focused on this model.

The R-square values tell us approximately how much variation in the outcome is explained by the model. The Nagelkerke R-square suggests that the model explains roughly $40 \%$ of the variation in the outcome. The Rsquare values are approximations and should not be overly emphasized. These pseudo-R-square estimates cannot reach high values by design (Meyers et al., 2016). Tabachnick and Fidell (2007) suggest that, for large samples, a statistical difference between a fitted model and the observed frequencies may not indicate a poor model.

The estimated coefficients provide the nonlinear logistic function of the best combination of predictors. The significance of each coefficient varies. A typical criterion in logistic prediction, the Wald test (Tabachnick \& Fidell, 2007) is used to investigate if each variable significantly predicts response category. According to the Wald criterion, the Affiliation variable reliably predicts the business expansion type $(\mathrm{p}<0.05)$. Of the control variables, $\mathrm{HQ}$ and Region are significant $(\mathrm{p}<0.001)$. The variable GDPHQ is statistically significant, however the value approximating zero makes this predictor irrelevant. These results indicate that affiliation type affects the business expansion type, irrespective of home and host country conditions, ownership or geography. The same criterion shows that business expansion type (international or domestic) is not distinguished on the basis of home country GDP. Business expansion in countries where the gross fixed capital formation is higher is not more likely to originate from outside the country. The results find no support for a predictive connection between international business expansion and ownership status. Type of industry is not significant. We can conclude from the statistical analysis that international business expansion depends on affiliation standing as parent, subsidiary, joint-venture or independent company, and also on geography (home and host region).

To identify the effect of each significant predictor category on the dependent variable (international business expansion as opposed to domestic business expansion), the inquiry is expanded with categorical variables analysis (estimating the exponentiated coefficients). The results allow for the interpretation of the odds ratios. Comparisons can directly be made with each of the reference categories. The reference categories for each significant predictor are, respectively: independent companies; locations other than Canada, Europe and the U.S. for the initiation of expansion; and the U.S. as the region where business expansion is taking place. These references are selected for their value in understanding the predictors in the contexts of: business group affiliation versus no affiliation at all; home location inside the three selected regions of focus versus outside the regions; and host locations with fewer instances of international expansion versus the region with most international expansion. Table 4 shows the odds ratio for each significant variable category.

Table-4. Categorical variables analysis.

\begin{tabular}{l|c|c|c|c}
\hline Variables & Coefficient & Wald & Sig. & Exp(B) \\
\hline Affiliation: Independent ${ }^{\mathrm{t}}$ & & 7.731 & .050 & \\
\hline Affiliation: Parent & $.679^{*}$ & 6.023 & .014 & 1.971 \\
\hline Affiliation: Subsidiary & -.030 & .009 & .923 & .971 \\
\hline Affiliation: Joint Venture & .317 & .067 & .796 & 1.374 \\
\hline HQ: Other & & 34.611 & .000 & \\
\hline HQ: Canada & -26.288 & .000 & .997 & .000 \\
\hline HQ: Europe & -21.952 & .000 & .998 & .000 \\
\hline HQ: U.S. & -21.929 & .000 & .998 & .000 \\
\hline Region: U.S. & & 51.719 & .000 & \\
\hline Region: Canada & $3.779^{* *}$ & 51.392 & .000 & 43.773 \\
\hline Region: Europe & .341 & 1.050 & .306 & 1.406 \\
\hline Notes: ${ }^{\mathrm{t}}$ are reference categories; ${ }^{*} \mathrm{p}<0.05,{ }^{* *} \mathrm{p}<0.001$. & & & &
\end{tabular}

Odds ratios allow for comparative interpretations of categories, relative to the reference categories. Notably, the findings described below are in this comparative context. The only category that is statistically significant for 
affiliation in reference to independent companies is the parent company category. The exponentiated coefficient reveals that parent companies are 1.971 times more likely then independent companies to expand internationally. For the location where from the expansion originates, only locations other than Canada, Europe and the U.S. are statistically significant in predicting international business expansion. Using the home location outside the focus areas as a baseline is a good "test" of the model and it allows us to conclude on the likelihood of international expansion from home locations inside the selected regions of focus. The analysis shows that we can only predict international expansion for the companies outside the focus regions. We cannot predict international expansion from companies expanding from countries inside any of the three regions. Finally, the analysis provides meaningful details in regards to the predictive power of the host region of expansion. Canada is the only region that is statistically significant for the region where expansion is taking place, with instances of international expansion 43.773 times more likely than in the U.S.

\section{DISCUSSION}

\subsection{Predictors of International Business Expansion}

The empirical analysis succeeds in identifying factors that determine the probability of international expansion. The model is in accord with the big picture view on the international versus domestic business expansion, taking into account predictors that are also overarching for the location, company types and geography. The results provide an overall image of the factors that determine international expansion.

The results find no support for the first hypothesis, with the size of the home economy making no difference in whether companies expand internationally or nationally. Strong domestic economies may offer good expansion opportunities in the home market. Equally, a large economy may allow companies to build the scale, capabilities and risk management capabilities to approach overseas growth. This finding may be encouraging for the selected regions' national policies to support local business activity and investments from outside their borders. The size of the economy equally affects national and international business expansion. For the second hypothesis, the analysis discovers that capital formation growth in the country where the expansion is happening does not impact international business activity. High economic growth may entice business expansion from domestic and international sources alike. The findings related to home and host country conditions are important. Results indicate that market attractiveness may provide motivation for both domestic and international expansion, and economic growth may sustain domestic business growth but also investments from abroad.

The third hypothesis posits that ownership status can predict the business expansion orientation, and that public companies may benefit from better access to capital and higher liquidity than private companies, thus accessing more funds to back international expansion. The results do not find that the ownership predicts international expansion. One particular company attribute, a company's affiliation position, predicts international versus national expansion. The results support the fourth hypothesis. Existing literature has been tentative in its findings about the kind of companies that expand internationally. The affiliation type has never been the main focus of previous research. This situation places high value on the findings of the current study that parent companies are almost two times more likely then independent companies to expand internationally. Relative to independent companies, subsidiaries and joint ventures are not more likely to expand internationally versus nationally. Parent companies may have more advantages in knowledge (e.g., assimilated know-how from companies in their network) and financial capabilities (e.g., internal capital markets or better access to external capital due to scale and reputation) than independent companies. These explanations are aligned with ideas posited by previous research. Parent companies may have the size and the appetite to undertake and sustain international investment.

The results provide important conclusions in regards to the regional location and scope of international business expansion. The study focuses on expansion happening only in the three regions: Canada, Europe and the United States of America. Instances of business expansion from countries in the same regions are considered, as 
well as from countries outside these regions. Thus, the investigation is focused on international business development in the three areas (Canada, Europe and the U.S.), within, across and from these areas as well as from the outside. International versus domestic expansion cannot be predicted to originate from companies in any of the three regions of focus. On the other hand, the region where the expansion is taking place can predict whether the investment will be international and not from a domestic company. If an expansion instance takes place in Canada, it is more likely to come from abroad than it would be if the expansion was in the U.S. This may suggest that, relative to the U.S., Canada exerts more of a pull of business expansion efforts from abroad.

The results do not identify the industry as a predicting factor for international expansion. Despite some literature on the importance of the industry sector for international actions, this analysis does not support it as a significant variable that may predict international versus home-country expansion.

\subsection{Implications and Contributions}

This study contributes to international business research in three ways. It first adds to the growing literature on the importance of company characteristics in relation to its international activity. The connection between affiliation and cross-borders expansion is original. Previous work has typically addressed the value of business group belonging for a company's performance or survival. Studies explored the benefits of networking and accessing internal capital. As mentioned in the literature review, group affiliation's effect on investment appetite and location was also posited to be mitigated by country and institutional contexts. The current study provides a key piece of information to investigations involving business group affiliation, explicitly identifying an affiliation position as a predictor of international business development. Specifically, the analysis shows a direct link between a parent position and the likelihood to expand outside national borders. The findings on how different types of group affiliation influence international expansion have implications for corporate managers of both business group affiliated and standalone companies. Parent firms may be better positioned for international expansion. The analysis outcomes inform the managers on the type of businesses they are likely to compete against when expanding internationally. The results may also suggest that strong control and influence as a parent increases the likelihood to engage across borders.

As a second area of contribution, the findings complement prior studies on the importance of location, both as related to internationalization and business activity in general. The current study takes into consideration the geography of expansion in multiple ways: as the economic situation of country where expansion originates and of the country where expansion materializes, as home region of the expanding company, and as region where the expansion occurs. The economic situation does not increase the probability of international expansion instances the home economy size do not increase or decrease the likelihood of international versus national expansion, nor does the growth in the region where expansion takes place. Outcomes related to the home region do not distinguish the odds of international expansion among the three regions as origins of business growth. A key finding is that the region where expansion occurs affects the probability of international expansion, with Canada showing increased comparative odds for international expansion.

The findings are important for multilateral and national policy. They point out to the pressing needs to maintain and cultivate regional connections and positive trade and investment movements. This is particularly meaningful in the context of the regions included in this study. The findings apply within and across United Kingdom, the European Union, Canada, and the United States. These locations are the center of trade discussions. The information on what may predict international business expansion here adds to the knowledge on how countries and regions are inter-connected. The results of this research give legitimacy to macroeconomic policies that prioritize inclusion, growth and resilience of domestic and foreign organizations.

The third added knowledge provided by this study relates to the finding that industry sector bears no impact on the type of expansion. Prior research focused more exclusively on activity patterns and motivations of companies 
in particular industries. When considering the big picture of business expansion, the current research finds that international expansion is likely to come from any industry sector. Executives are advised to consider the instances of international and domestic expansion pursued by the leadership of their rival or comparator companies, with an understanding that international expansion can be a path for growth in any industry.

\subsection{Limitations and Future Lines of Research}

The study set out to determine if there is a relationship between the kind of business expansion - international or domestic - and variables related to home and host locations and company descriptors. The analysis finds that affiliation is a significant predictor of international expansion, with parent companies more likely to engage internationally. The results also point out to some geography effects, most importantly, the fact that the expansion location affects the probability of international business expansion. This research is not free from limitations. The understanding is that the overall expansion review does not necessitate the inclusion of more specific variables (such as entry mode choice). Despite the arguments that support the big picture view, the study may be weakened by a simplified model that does not include all possible independent variables, such as firm size and characteristics. Nevertheless, the large data sample and the strength of the statistical association support the robustness of the current model.

A limitation but also a good avenue for future research is the environmental characteristics of expansion target countries. New work can explore regulative and normative dimensions of the host country environments. More understanding can be gained on how specific factors in a host and also home country affect the predilection for international expansion. Political environments or legal hazards, for example, could moderate the propensity to expand internationally. Again, the good fit of the simpler model included here supports the idea that these variables were not missed out in the analysis. Nevertheless, they could provide valuable investigations on more specific topics. In the same vein, the present analysis investigates how group affiliation affects international expansion. A limitation and a future line of research may be to account for each affiliation type's internal characteristics, such as information processing and decision-making efficiencies.

Recent literature (e.g., (Stallkamp, Pinkham, Schotter, \& Buchel, 2018)) called for more international business and foreign direct investment research that integrates geospatial analysis. The current paper is restricted to Europe and Northern America. A global study could be useful to shed more light on the theoretical model. This paper attempts to provide answers for the type of the expansion (international versus domestic). The work is not answering why and when some firms expand their operations and it is not comparing industry-wide international expansion paths. Future research could further enrich these understandings of expansion. The use of the time series data in a random sampling research design is a potential limitation of the present study. The procedure is justified by the examination of an evolving phenomenon that should be studied over a long time.

\section{CONCLUSIONS}

As an overall analysis of determinants of international versus national expansion, this study provides the broad strokes of the factors that increase the probability of international business development. The past decade provides a panel of data indicating that business affiliation position significantly impacts the likelihood of international expansion. Information obtained from the analysis of these data also finds for differences in expansion depending on geographical location. The research paints the picture of expansion at a macro level, with predictive findings on the potential origins of investments. In addition to the implications for managers and economists, the present research offers insights for policy-makers, such as the idea that inflows of investments can be sought after from parent companies with higher chances of success. The current paper's implications are wide-reaching to national, regional and global policy. The outcomes align with other research (e.g., (Jalilian, Kirkpatrick, \& Parker, 2006)) that explore the challenges to provide an environment conducive to mutually beneficial trade and investment. 
Funding: This study received no specific financial support.

Competing Interests: The author declares that there are no conflicts of interests regarding the publication of this paper.

\section{REFERENCES}

Allen, L., \& Pantzalis, C. (1996). Valuation of the operating flexibility of multinational corporations. Journal of International Business Studies, 27(4), 633-653. Available at: https://doi.org/10.1057/palgrave.jibs.8490147.

Ambos, T. C., Andersson, U., \& Birkinshaw, J. (2010). What are the consequences of initiative-taking in multinational subsidiaries? Journal of International Business Studies, 41(7), 1099-1118. Available at: https://doi.org/10.1057/jibs.2010.19.

Anand, J., \& Delios, A. (2002). Absolute and relative resources as determinants of international acquisitions. Strategic Management Journal, 23(2), 119-134. Available at: https://doi.org/10.1002/smj.215.

Ariño, A. (2015). Semiglobalization: A relevant reality. Emerging Economies and Multinational Enterprises (Advances in International Management, 28 35-42. Available at: https://doi.org/10.1108/s 1571-502720150000028004.

Astivia, O. O., Gadermann, A., \& Guhn, M. (2019). The relationship between statistical power and predictor distribution in multilevel logistic regression: A simulation-based approach. BMC Medical Research Methodology, 19(1), 97-97. Available at: https://doi.org/10.1186/s12874-019-0742-8.

Boso, N., Oghazi, P., \& Hultman, M. (2017). International entrepreneurial orientation and regional expansion. Entrepreneurship \&̊ Regional Development, 29(1-2), 4-26. Available at: https://doi.org/10.1080/08985626.2016.1255430.

Buckley, P., \& Casson, M. C. (1976). The future of the multinational enterprise. London: Homes and Meier.

Chakraborty, C., \& Basu, P. (2002). Foreign direct investment and growth in India: A cointegration approach. Applied Economics, 34(9), 106 1-1073. Available at: https://doi.org/10.1080/00036840110074079.

Christian, A. V., Zhang, Y., \& Salifou, C. K. (2016). Country selection for international expansion: TOPSIS method analysis. Modern Economy, 7(04), 470. Available at: https://doi.org/10.4236/me.2016.74052.

Desai, M. A., Foley, C. F., \& Hines Jr, J. R. (2005). Foreign direct investment and the domestic capital stock. American Economic Review, 95(2), 33-38.

Dunning, J. H. (1988). The eclectic paradigm of international production: A restatement and some possible extensions. Journal of International Business Studies, 19(1), 1-31.

Dunning, J. H. (1993). Multinational enterprises and the global economy. Wokingham: Addison Wesley.

Dunning, J. H., \& Lundan, S. M. (2008). Multinational enterprises and the global economy (2nd ed.). Cheltenham: Edward Elgar.

Gaur, A., Pattnaik, C., Lee, J. Y., \& Singh, D. A. (2016). The network advantage of MNCs and business groups and foreign subsidiary performance. Paper presented at the In Academy of Management Proceedings: Briarcliff Manor, NY: Academy of Management.

Gaur, A. S., \& Kumar, V. (2009). International diversification, business group affiliation and firm performance: Empirical evidence from India. British Journal of Management, 2O(2), 172-186. Available at: https://doi.org/10.1111/j.14678551.2007.00558.x.

Ghemawat, P. (2005). Regional strategies for global leadership. Harvard Business Review, 83(12), 98-108.

Gibescu, O. (2010). Does the gross fixed capital formation represent a factor for supporting the economic growth? Germany: University Library of Munich.

Gupta, G., \& Mahakud, J. (2018). Business group affiliation and corporate investment: Evidence from Indian companies. Journal of Management Research, 18(1), 56-67.

Hymer, S. (1976). The international operations of national firms. Cambridge: MIT Press.

Ibeh, K., Wilson, J., \& Chizema, A. (2012). The internationalization of African firms 1995-2011: Review and implications. Thunderbird International Business Review, 54(4), 41 1-427. Available at: https://doi.org/10.1002/tie.21473. 
Jalilian, H., Kirkpatrick, C., \& Parker, D. (2006). Creating the conditions for international business expansion: The impact of regulation on economic growth in developing countries-a cross-country analysis. In Amann, E. (Ed.), Regulating development: Evidence from Africa and Latin America (pp. 11-38). Cheltenham, UK: Edward Elgar.

Li, Y., Zhang, Y. A., \& Shi, W. (2019). Navigating geographic and cultural distances in international expansion: The paradoxical roles of firm size, age, and ownership. Strategic Management Journal, 41(5), 921-949. Available at: https://doi.org/10.1002/smj.3098.

Lynch, R., \& Jin, Z. (2016). Exploring the institutional perspective on international business expansion: Towards a more detailed conceptual framework. Journal of Innovation $छ$ Knowledge, 1(2), 117-124. Available at: https://doi.org/10.1016/j.jik.2016.01.001.

Maalouf, M. (2011). Logistic regression in data analysis: An overview. International Journal of Data Analysis Techniques and Strategies, 3(3), 281-299. Available at: https://doi.org/10.1504/ijdats.2011.041335.

Mauri, A., Song, S., \& Neiva de Figueiredo, J. (2017). Determinants of corporate international expansion beyond the home region: An empirical examination of US multinational enterprises expansion to Europe and Asia-pacific. Global Strategy Journal, 7(4), 400-426. Available at: https://doi.org/10.1002/gsj.1155.

Meyers, L. S., Gamst, G., \& Guarino, A. J. (2016). Applied multivariate research: Design and interpretation. Thousand Oaks, CA: Sage Publications.

Mohr, A., \& Batsakis, G. (2018). Firm resources, cultural distance and simultaneous international expansion in the retail sector. International Business Review, 27(1), 113-124. Available at: https://doi.org/10.1016/j.ibusrev.2017.05.010.

Moore, C., Fernie, J., \& Burt, S. (2000). Brands without boundaries: The internationalisation of the designer retailer's brand. European Journal of Marketing, 34(8), 919-937. Available at: https://doi.org/10.1108/03090560010331414.

North, D. C. (1990). Institutions, institutional change and economic performance. Cambridge: Cambridge University Press.

Nuruzzaman, N., \& Singh, D. (2017). Home country political and legal hazards and international expansion of emerging market firms. Paper presented at the In Academy of Management Proceedings: Briarcliff Manor, NY: Academy of Management.

Oh, C. H., Kim, M., \& Shin, J. (2019). Paths and geographic scope of international expansion across industries. International Business Reviere, 28(3), 560-574.

Qian, G., Li, L., \& Rugman, A. M. (2013). Liability of country foreignness and liability of regional foreignness: Their effects on geographic diversification and firm performance. Journal of International Business Studies, 44(6), 635-647. Available at: https://doi.org/10.1057/jibs.2013.21.

Rienda, L., Claver, E., \& Quer, D. (2013). The internationalisation of Indian multinationals: Determinants of expansion through acquisitions. Journal of the Asia Pacific Economy, 18(1), 115-132. Available at: https://doi.org/10.1080/13547860.2012.742705.

Rugman, A. M. (1981). A test of internalization theory. Managerial and Decision Economics, 2(4), 211 -2 19.

Stallkamp, M., Pinkham, B. C., Schotter, A. P., \& Buchel, O. (2018). Core or periphery? The effects of country-of-origin agglomerations on the within-country expansion of MNEs. Journal of International Business Studies, 49(8), 942-966.

Tabachnick, B. G., \& Fidell, L. S. (2007). Using multivariate statistics. Boston, MA: Allyn and Bacon.

Verbeke, A., \& Kano, L. (2012). An internalization theory rationale for MNE regional strategy. Multinational Business Review, $20(2), 135-152$.

Views and opinions expressed in this article are the views and opinions of the author(s), International Journal of Business, Economics and Management shall not be responsible or answerable for any loss, damage or liability etc. caused in relation to/arising out of the use of the content. 